\title{
HOME-RANGE SIZE AND OVERLAP OF SYMPATRIC MALE MULE AND WHITE-TAILED DEER IN TEXAS
}

\author{
Kristina J. Brunjes ${ }^{1}$, Warren B. Ballard ${ }^{1,6}$, Mary H. Humphrey², Fielding Harwell ${ }^{3}$, \\ Nancy E. McIntyre ${ }^{4}$, Paul R. Krausman ${ }^{5}$, and Mark C. Wallace ${ }^{1}$
}

\begin{abstract}
Information about the ecology of sympatric male deer is limited, which may influence management strategies for these species. We estimated home-range and core-area sizes and overlap, and survival of sympatric male desert mule deer (Odocoileus hemionus eremicus) and white-tailed deer (Odocoileus virginianus) in west central Texas. We captured 18 males of each species, fitted them with radio-collars, and monitored them for mortality from 2000 through 2003. We calculated home ranges for 7 males of each species in 2001 and 2002. Home-range sizes of mule deer $\left(8.8 \mathrm{~km}^{2}\right)$ and white-tailed deer $\left(7.4 \mathrm{~km}^{2}\right)$ were similar. Interspecific home-range overlap was less common than intraspecific overlap. Mean annual survival was $0.76\left(s_{\bar{x}}=0.04\right)$ for mule deer and $0.80\left(s_{\bar{x}}=0.06\right)$ for white-tailed deer. The high degree of home-range overlap and similar survival between the 2 deer species suggest that management targeting only 1 species may be unfeasible.
\end{abstract}

Key words: home range, males, movements, survival, mule deer, white-tailed deer.

In Texas, the distributions of desert mule deer (Odocoileus hemionus eremicus) and white-tailed deer (Odocoileus virginianus) overlap in portions of the Trans-Pecos region, the western edge of the Edwards Plateau, and the Panhandle region (Smith 1987). Landowners and wildlife managers have become concerned in recent decades as white-tailed deer have become more abundant in areas previously considered desert mule deer habitat (Harwell and Gore 1981), even as mule deer have decreased or disappeared entirely from some areas now inhabited by white-tailed deer (Wiggers and Beasom 1986). The amount of area used by male deer and their survival are of interest to private landowners and managers due to the significant economic contribution of hunting in Texas (Harveson et al. 2000). Income generated by hunting leases or other wildlife recreation can supplement or even exceed that from traditional livestock operations (Butler and Workman 1993). Because of higher bag limits and longer seasons for hunting whitetailed deer (Texas Parks and Wildlife Department 2000, 2001, 2002), some managers may wish to revise management activities to benefit primarily white-tailed deer, whereas others may prefer to reverse the increase of whitetailed deer in the area and favor mule deer.

Our objectives were to determine whether home-range sizes differed between the species and to determine the degree of home-range and core-area overlap between the species. Because allopatric male white-tailed deer in semiarid and arid environments have smaller home ranges (Michael 1965, Gallina et al. 1997) than male mule deer in arid environs have (Dickinson and Garner 1979, Relyea et al. 2000), we predicted that mule deer would have larger home ranges than white-tailed deer. However, we expected high home-range overlap between the species, as neither is territorial and they have similar diets (Anthony 1972, Krausman 1978).

We conducted our study on 5 contiguous ranches (approximately $323 \mathrm{~km}^{2}$ total) in the northwestern corner of Crockett County, Texas. Estimated deer densities (both sexes) from a helicopter census of the entire area conducted in 2001 were 2.4 mule deer $\cdot \mathrm{km}^{-2}$ and 1.6 white-tailed deer $\cdot \mathrm{km}^{-2}$ (Brunjes et al. 2006). The site was located on the western edge of the Edwards Plateau. Low elevations were dominated by mesquite (Prosopis sp.), creosote

\footnotetext{
${ }^{1}$ Department of Natural Resources Management, Box 42125, Texas Tech University, Lubbock, TX 79409.

${ }^{2}$ Texas Parks and Wildlife Department, Sonora, TX 76950.

${ }^{3}$ Texas Parks and Wildlife Department, Kerrville, TX 78028.

${ }^{4}$ Department of Biological Sciences, Texas Tech University, Lubbock, TX 79409.

${ }^{5}$ School of Natural Resources, University of Arizona, Tucson, AZ 85721.

${ }^{6}$ Corresponding author. E-mail: warren.ballard@ttu.edu
} 
(Larrea tridentata), tarbush (Flourensis cernua), and prickly pear (Opuntia sp.). Juniper (Juniperus sp.) was the dominant woody species on slopes and mesa tops. Washes supported dense thickets of hackberry trees (Celtis occidentalis). The more xeric slopes supported aridland plants such as yuccas (Yucca sp.) and ocotillo (Fouquieria splendens; Correll and Johnston 1970).

Topography consisted of broad, level plateaus, rolling hills, and steep canyon walls. Elevation ranged from 700 to $915 \mathrm{~m}$. Mean annual precipitation for 2000-2002 was $25 \mathrm{~cm}$; the average for 1963-1997 was $43 \mathrm{~cm}$. Most rainfall occurred from May to September, with highest amounts usually falling in September. The average annual low temperature was $10^{\circ} \mathrm{C}$; the average annual high was $26{ }^{\circ} \mathrm{C}$. Temperatures ranged from a minimum daily low of -1 ${ }^{\circ} \mathrm{C}$ to a maximum daily high of $16{ }^{\circ} \mathrm{C}$ in winter and from 16 to $32{ }^{\circ} \mathrm{C}$ in summer (National Oceanic and Atmospheric Administration 2000, 2001, 2002).

Livestock production, oil production, and hunting were the primary land-use activities in the region. On 2-3 February 2000 and 30 January 2001, personnel from Holt Helicopters (Uvalde, TX) captured deer with a net gun fired from a helicopter (Krausman et al. 1985). We recorded sex and condition of each animal and estimated the age of deer by the tooth wear and replacement method (Severinghaus 1949, Robinette et al. 1957). We fitted each male deer with a numbered plastic eartag and a 500-g radio-collar with a mortality sensor (Telonics, Mesa, AZ).

We conducted radio-tracking with a truckmounted null-peak system consisting of two 4element Yagi antennas mounted on a rotating, telescoping boom in the bed of a truck. We used the software program LOAS (Ecological Software Solutions, Sacramento, CA) to calculate deer locations from telemetry bearings. We located collared males $>2$ times per month during January through August 2000-2002 to estimate home ranges. Using a minimum of 30 locations, we calculated home ranges and core areas for 7 deer of each species for 2001 and 2002. Individual deer locations were not triangulated during September through mid-January, because landowners restricted our access to their property during deer-hunting season. We rotated the timing of relocations sequentially through 3 time blocks (05:00-10:59, 11:00-
16:59, and 17:00-24:00). We used the Animal Movement extension (Hooge and Eichenlaub 2000) for ArcView GIS software (ESRI, www .esri.com) to calculate $95 \%$ and $50 \%$ fixed-kernel home-range estimates and minimum convex polygons (MCP) to facilitate comparison to previous studies. We calculated $50 \%$ kernel home ranges as an approximation of each animal's core area (Loveridge and Macdonald 2003).

We used ArcView to identify the polygon created when the home ranges of 2 individuals overlapped. For comparisons, each overlap polygon was assigned to 1 of 3 dyads-mule deer:mule deer (MM), mule deer: white-tailed deer $(\mathrm{MW})$, or white-tailed deer:white-tailed deer $(W W)$. If at least one location of either animal occurred within that overlap polygon, we calculated an overlap index using the following ratio:

$$
\left[\left(n_{1}+n_{2}\right) /\left(N_{1}+N_{2}\right)\right] \times 100,
$$

where $n_{1}$ and $n_{2}$ refer to respective number of locations for each deer within the overlap polygon, and $N_{1}$ and $N_{2}$ refer to the respective total number of locations used to calculate the home range for each deer (Chamberlain and Leopold 2002). We used this same procedure to calculate overlap indices for core areas.

We used Levene's test to check for homogeneity of variance for all comparisons and we examined residuals for normality (Zar 1999, Bryce et al. 2002). We used ANOVA $(\alpha=0.05)$ to compare mean home-range sizes between years and ages within species and between species, and to test for interactions (White and Garrott 1990). Because of unequal sample sizes, Fisher's LSD test was used for means separation in overlap comparisons.

We captured and fitted 10 males of each species with radio-collars in January 2000. In January 2001, we captured and collared an additional 8 males of each species. Mean age at capture was 3.5 years (range 3.5-4.5) for mule deer and 4.5 years (range 3.5-6.5) for white-tailed deer. We did not have any deer with $>30$ locations during 2000 to calculate home ranges for.

Average bearing error was $\pm 7^{\circ}$ based on triangulated locations of collars in known locations. Levene's test for homogeneity of variance was not significant for any comparison at $\alpha=0.05$, and examination of residuals supported the assumption that the data were normally distributed. Of the 7 mule deer and 7 
TABLE 1. ANOVA comparison within and between adult male mule and white-tailed deer by year and age for 2 independent variables: $95 \%$ kernel home-range area and 50\% kernel core area. Deer were studied in west central Texas, January through August, 2001-2002.

\begin{tabular}{|c|c|c|c|c|c|}
\hline Estimate & Species, sample size & Variable & $\mathrm{df}$ & $F$ & $P$ \\
\hline \multirow[t]{8}{*}{$95 \%$ kernel } & \multirow[t]{3}{*}{ Mule deer, $n=7$} & Age & 2 & 0.22 & 0.81 \\
\hline & & Year & 1 & 1.00 & 0.34 \\
\hline & & Age $\times$ Year & 3 & 10.9 & 0.41 \\
\hline & \multirow[t]{3}{*}{ White-tailed deer, $n=7$} & Age & 4 & 1.47 & 0.34 \\
\hline & & Year & 1 & 0.06 & 0.81 \\
\hline & & Age $\times$ Year & 6 & 1.43 & 0.41 \\
\hline & \multirow[t]{2}{*}{ Combined, $n=14$} & Species $\times$ Year & 3 & 0.87 & 0.47 \\
\hline & & Species & 1 & 0.46 & 0.51 \\
\hline \multirow{8}{*}{$\begin{array}{l}50 \% \text { kernel } \\
\quad(\text { core area })\end{array}$} & \multirow[t]{3}{*}{ Mule deer, $n=7$} & Age & 2 & 0.15 & 0.87 \\
\hline & & Year & 1 & 1.80 & 0.21 \\
\hline & & Age $\times$ Year & 3 & 1.45 & 0.93 \\
\hline & \multirow[t]{3}{*}{ White-tailed deer, $n=7$} & Age & 4 & 1.20 & 0.41 \\
\hline & & Year & 1 & 0.34 & 0.57 \\
\hline & & Age $\times$ Year & 6 & 0.71 & 0.69 \\
\hline & \multirow[t]{2}{*}{ Combined, $n=14$} & Species $\times$ Year & 3 & 0.74 & 0.54 \\
\hline & & Species & 1 & 0.15 & 0.71 \\
\hline
\end{tabular}

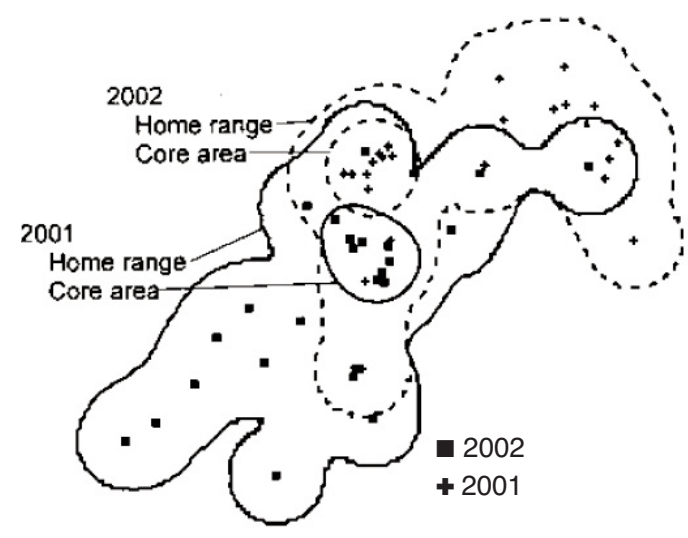

Fig. 1. An example of overlapping 2001 and 2002 home ranges and core areas for adult male mule deer in west central Texas.

white-tailed deer for which $>30$ locations per year were available, 5 mule deer and 3 whitetailed deer were tracked in both years, and we averaged their calculated home-range size for later analyses. The remaining deer had $>30$ locations per year for only 1 of the 2 years. Within each species, neither home-range size nor core-area size differed between years or ages, nor was there a year $\times$ age interaction or a species $\times$ year interaction (Table 1 ), so we pooled data for each species. Home-range size and core-area size did not differ between species (Table 2). Mean home-range size for
TABLE 2. Mean percentage overlap indices for $95 \%$ kernel home ranges and $50 \%$ kernel core areas of adult male mule and white-tailed deer in west central Texas, January through August, 2001-2002. Indices for home range and core area were compared among species using ANOVA. Fisher's LSD was used for means separation when ANOVA resuts were significant. Means followed by the same letter within a year were not different at $\alpha=0.05$.

\begin{tabular}{lcrcr}
\hline & Dyad $^{\mathrm{a}}$ & $n$ & Average overlap & \multicolumn{1}{c}{$s_{\bar{x}}$} \\
\hline \multirow{4}{*}{ Home ranges } & MM & 17 & $29.32 \mathrm{a}$ & 6.25 \\
& WW & 15 & $44.32 \mathrm{a}$ & 10.08 \\
Core areas & MW & 10 & $8.57 \mathrm{~b}$ & 3.24 \\
& MM & 3 & 39.10 & 19.75 \\
& WW & 5 & 48.36 & 10.84 \\
\hline
\end{tabular}

aFor conparisons each overlap polygon was assigned to 1 of 3 dyads: mule deer: mule deer (MM), mule deer: white-tailed deer (MW), or white-tailed deer: white-tailed deer $(\mathrm{WW})$

mule deer was $8.8 \mathrm{~km}^{2}\left(s_{\bar{x}}=1.6\right)$ and mean core-area size was $1.0 \mathrm{~km}^{2}\left(s_{\bar{x}}=0.2\right)$; mean home-range size for white-tailed deer was 7.4 $\mathrm{km}^{2}\left(s_{\bar{x}}=1.3\right)$ and mean core-area size was $1.1 \mathrm{~km}^{2}\left(s_{\bar{x}}=0.2\right)$. The home range calculated for 2002 overlapped the home range calculated for 2001 for 4 mule deer and 3 whitetailed deer (Fig. 1). Only 1 mule deer shifted home range between years. The mean proportion of the 2001 home range that was overlapped by the 2002 home range was $0.4\left(s_{\bar{x}}=\right.$ $0.2)$ for mule deer and $0.5\left(s_{\bar{x}}=0.1\right)$ for whitetailed deer. The amount of overlap between years was not different between species $\left(F_{1}=\right.$ $0.15, P=0.71)$. 


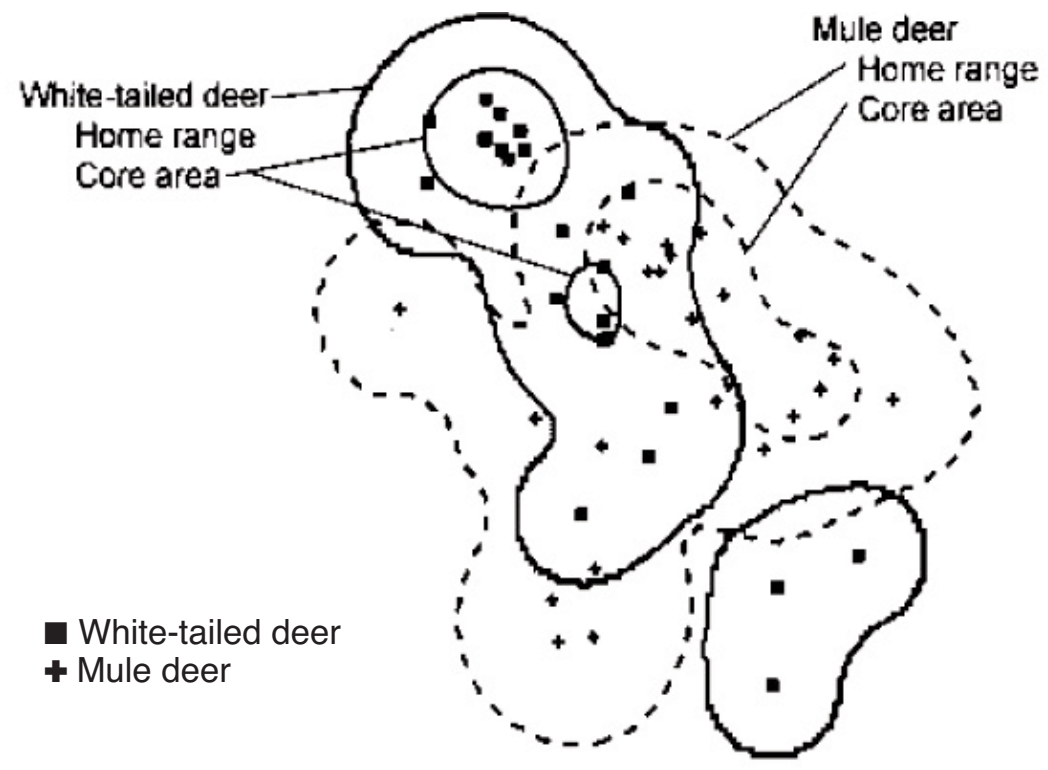

Fig. 2. An example of overlapping home ranges and core areas for adult male mule and white-tailed deer in west central Texas, January-August, 2002.

During both years, the home range of every study animal was overlapped by the home range of more than one other study animal. Each study animal's home range overlapped the home range of more than one collared individual of the other species (Table 2), except one white-tailed deer whose home range did not overlap the home range of any collared mule deer. Overlapping core areas between collared animals were less common than overlapping home ranges (Table 2). Home-range and core-area overlap indices did not differ between years within dyads (home range: $F_{1}$ $=0.29, P=0.59$; core area: $F_{1}=0.14, P=$ 0.7 ), nor did we detect a year $\times$ dyad interaction (home range: $F_{2}=2.41, P=0.10$; core area: $\left.F_{1}=1.60, P=0.29\right)$. Home-range overlap indices did not differ between the MM and WW dyads, but MW overlap indices were less than those of either intraspecific dyad $\left(F_{2}\right.$ $=7.17, P=0.002)$. We observed only one instance in which the calculated core areas overlapped for a mule deer and a white-tailed deer, but no locations of either species occurred within the overlap polygon. Core-area overlap indices did not differ between $\mathrm{MM}$ and WW dyads $\left(F_{1}=1.25, P=0.35\right)$.

Our results did not support our initial predictions. However, differences in home-range size may not have been detectable because of our small sample size and the difficulty of tracking deer. According to competition theory, 2 species with similar life history traits should partition resources when sympatric (Hardin 1960). Diet does not appear to drive habitat partitioning between these species (Hill and Harris 1943, Allen 1968, Martinka 1968, Krausman 1978), suggesting that some other resource (e.g., space) was driving resource partitioning. Equivalent home-range sizes may be a direct result of sympatry, as both species exist on the same forage resource. Although the larger body mass of mule deer suggests they need larger home ranges, habitat productivity appears to be a more important influence on ungulate home-range size (Relyea et al. 2000). The observed interspecific homerange overlap indicated that habitat partitioning may have occurred on a temporal scale or at a finer spatial scale than can be detected by our home-range-level analyses.

Core-area overlap indicated a greater potential for competition than home-range overlap (Wauters and Dhondt 1985), yet interspecific core-area overlap occurred only once. This avoidance could be an artifact of data collection, as deer spend much of their time bedded down compared to the time they spend on foraging and other activities. Thus, the smaller degree of overlap between the species' core 
areas could be due, in part, to differences in preferred bedding sites, as mule deer prefer bed sites with less cover and steeper slopes (Avey et al. 2003) than those preferred by white-tailed deer. However, we obtained most locations during crepuscular periods to improve our sample of non-bedded deer. Avoidance by individuals of the core areas of the other species may indicate that interspecific competition influenced the spatial distribution of deer more than intraspecific competition.

Individuals of both species appeared to maintain their home ranges within the same general area during both years. Only one male, a 4.5-year-old mule deer, completely shifted his home range between 2001 and 2002. This fidelity, coupled with significant interspecific home-range overlap, suggested that neither species was actively driving the other out of the area and that spatial coexistence was stable.

Because we were unable to track deer during September through December, our estimates of home range are probably underestimates, as male deer tend to increase movements outside of their home range during the breeding season (Rodgers et al. 1978, Dickinson and Garner 1979, Relyea and Demarais 1994, Gallina et al. 1997). Our results are consistent with other research on sympatric mule deer and white-tailed deer (e.g., Martinka 1968, Anthony and Smith 1977, Krausman 1978, Wood et al. 1989) that suggests that the 2 species coexist via spatial segregation. However, the question remains: at what scale do these species partition the habitat? Avey et al. (2003) indicated that there was habitat separation between species, suggesting that managers might be able to manage habitat for both species. That this separation is occurring below the home-range scale is supported by our results on home-range and core-area size, and by the fact that the differences observed by Avey et al. 2003 occurred at the individual point locations of deer. The degree of homerange similarity and overlap we observed suggest that management to primarily benefit only one species may be difficult to conduct on a large scale (e.g., an entire ranch).

We thank C. Anderson, J. Brunjes, S. Dempsey, B. Hudgens, S. Peterson, R. Philips, and the L.D. Clark family for logistic support and field assistance. R. Carrera provided the Spanish translation. Funding and support for this research was provided by the Texas Parks and Wildlife Department, the Rob and Bessie Welder Wildlife Foundation, and the West Texas and Houston chapters of Safari Club International. This is College of Agricultural Sciences and Natural Resources technical publication T-9-1133.

\section{Literature Cited}

Allen, E.O. 1968. Range use, foods, condition, and productivity of white-tailed deer in Montana. Journal of Wildlife Management 32:130-141.

Anthony, R.G. 1972. Ecological relationships between mule deer and white-tailed deer in southeastern Arizona. Doctoral dissertation, University of Arizona, Tucson.

ANTHONY, R.G., AND N.S. Smith. 1977. Ecological relationships between mule deer and white-tailed deer in southeastern Arizona. Ecological Monographs 47: 255-277.

Avey, J.T., W.B. Ballard, M.C. Wallace, M.H. Humphrey, P.K. Krausman, F. Harwell, and E.B. Fish. 2003. Habitat relationships between sympatric mule deer and white-tailed deer in Texas. Southwestern Naturalist 48:644-653.

Brunjes, K.J., W.B. Ballard, M.H. Humphrey, F. HarWell, N.E. McIntyre, P.R. Krausman, and M.C. WALLACE. 2006. Habitat use by sympatric mule and white-tailed deer in Texas. Journal of Wildlife Management 79:1351-1359.

Bryce, J., P.J. Johnson, and D.W. Macdonald. 2002. Can niche use in red and grey squirrels offer clues for their apparent coexistence? Journal of Applied Ecology 39:875-887.

Butler, L.D., And J.P. Workman. 1993. Fee hunting in the Texas Trans Pecos area: a descriptive and economic analysis. Journal of Range Management 46:38-42.

Chamberlain, M.J., and B.D. Leopold. 2002. Spatiotemporal relationships among adult raccoons (Procyon lotor) in central Mississippi. American Midland Naturalist 148:297-308.

Correll, D.S., And M.C. Johnston. 1970. Manual of the vascular plants of Texas. Texas Research Foundation, Renner.

Dickinson, T.G., and G.W. Garner. 1979. Home range use and movements of desert mule deer in southwestern Texas. Proceedings of the Annual Conference of Southeastern Fish and Wildlife Agencies 33:267278.

Gallina, S., S. Mandujano, J. Bello, and C. Delfin 1997. Home-range size of white-tailed deer in northeastern Mexico. Pages 47-50 in J. DeVos, Jr., editor, Proceedings of the Deer/Elk Workshop. Rio Rico, AZ.

Hardin, G. 1960. The competitive exclusion principle. Science 131:1292-1297.

Harveson, L.A., M.E. Tewes, N.J. Silvy, and J. Rutledge. 2000. Prey use by mountain lions in southern Texas. Southwestern Naturalist 45:472-476.

Harwell, W.F., and H.G. Gore. 1981. White-tailed deer population trends. Job Performance Report, Federal Aid Project Number W-109-R-4, Job Number 1, Texas Parks and Wildlife Department, Austin. 
Hill, R.R., and D. HaRRis. 1943. Food preferences of Black Hills deer. Journal of Wildlife Management 7:233-235

Hooge P.N., and B. Eichenlaub. 2000. Animal Movement extension to ArcView. Version 2.0. Alaska Science Center, Biological Science Office, U.S. Geological Survey, Anchorage, AK.

Krausman, P.R. 1978. Forage relationship between two deer species in Big Bend National Park, Texas. Journal of Wildlife Management 42:101-107.

Krausman, P.R., J.J. Hervert, and L.L. Ordway. 1985. Capturing deer and mountain sheep with a net-gun. Wildlife Society Bulletin 13:71-73.

Loveridge, A.J., And D.W. Macdonald. 2003. Niche separation in sympatric jackals (Canis mesomelas and Canis adustus). Journal of Zoology 259:143-153.

MartinKa, C.J. 1968. Habitat relationships of white-tailed and mule deer in northern Montana. Journal of Wildlife Management 32:558-565.

MichaEL, E.D. 1965. Movements of white-tailed deer on the Welder Wildlife Refuge. Journal of Wildlife Management 29:44-52.

National Oceanic and Atmospheric Administration. 2000. Annual climatological summary; Big Lake 2, Midland, TX.

2001. Annual climatological summary; Big Lake 2 , Midland, TX.

2002. Annual climatological summary; Big Lake 2, Midland, TX.

Relyea, R.A., and S. Demarais. 1994. Activity of desert mule deer during the breeding season. Journal of Mammalogy 75:940-949.

Relyea, R.A., R.K. Lawrence, and S. Demarais. 2000. Home range of desert mule deer: testing the bodysize and habitat-productivity hypotheses. Journal of Wildlife Management 64:146-153.

Robinette, W.L., D.A. Jones, G. Rogers, and J.S. GashWILER. 1957. Notes on tooth development and wear for Rocky Mountain mule deer. Journal of Wildlife Management 21:134-153.
Rodgers, K.J., P.F. Ffolliott, and D.R. Patton. 1978. Home range and movement of five mule deer in a semidesert grass-shrub community. USDA Forest Service Research Note RM-355.

Severinghaus, C.A. 1949. Tooth development and wear as criteria of age in white-tailed deer. Journal of Wildlife Management 13:195-216.

SMITH, W.P. 1987. Dispersion and habitat use by sympatric Columbian white-tailed deer and Columbian blacktailed deer. Journal of Mammalogy 68:337-347.

Texas Parks and Wildlife Department. 2000. Outdoor annual-Texas hunting and fishing regulation summary. 4200 Smith School Road, Austin, TX 78744.

. 2001. Outdoor annual-Texas hunting and fishing regulation summary. 4200 Smith School Road, Austin, TX 78744 .

2002. Outdoor annual-Texas hunting and fishing regulation summary. 4200 Smith School Road, Austin, TX 78744 .

Whuters, L.A., AND A.A. DhOndt. 1985. Population dynamics and social behaviour of red squirrel populations in different habitats. Proceedings of the International Congress of Game Biologists 17:311318.

White, G.C., AND R.A. Garrott. 1990. Analysis of wildlife radio-tracking data. Academic Press, San Diego, CA.

Wiggers, E.P., AND S.L. BEASOM. 1986. Characterization of sympatric or adjacent habitats of two deer species in west Texas. Journal of Wildlife Management 50: $129-134$.

Wood, A.K., R.J. Mackie, and K.L. Hamlin. 1989. Ecology of sympatric populations of mule deer and white-tailed deer in a prairie environment. Montana Fish, Wildlife and Parks. 97 pp.

ZAR, J.H. 1999. Biostatistical analysis. 4th edition. PrenticeHall, Inc., Upper Saddle River, NJ.

Received 23 July 2007 Accepted 7 July 2008 